\title{
Water quality monitoring with emphasis on estimation of point and diffuse pollution sources
}

\author{
Albek E.A. ${ }^{1}$, Göncü S. ${ }^{1}$, Uygun B.Ş. ${ }^{1, *}$, Albek M. ${ }^{1}$, Avdan Z.Y. ${ }^{1}$, Güngör Ö. ${ }^{2}$ \\ ${ }^{1}$ Eskişehir Technical University, Department of Environmental Engineering, 26470, Eskişehir, Turkey \\ ${ }^{2}$ Bülent Ecevit University, Department of Environmental Engineering, Zonguldak, Turkey \\ Received: 09/10/2018, Accepted: 05/02/2019, Available online: 07/02/2019 \\ *to whom all correspondence should be addressed: e-mail: bsimsek1@eskisehir.edu.tr \\ https://doi.org/10.30955/gnj.002911
}

\section{Abstract}

Population growth, urbanization and anthropogenic activities are becoming a serious problem for water resources in Turkey, which necessitates their monitoring and maintenance of water quality. In this study, water quality was implemented in the Porsuk Stream in Inner Anatolia, Turkey. Water samples were collected at monthly intervals between the period of 2008-2010 at four selected stations. Twenty one water quality parameters were measured which are water temperature $(T), p H$, dissolved oxygen (DO), electrical conductivity (EC), salinity, turbidity, chloride, suspended solids, dissolved solids, organic nitrogen (Org- $\mathrm{N}$ ), ammonium nitrogen $\left(\mathrm{NH}_{3}-\mathrm{N}\right)$, nitrite nitrogen $\left(\mathrm{NO}_{2}-\mathrm{N}\right)$, nitrate nitrogen $\left(\mathrm{NO}_{3}-\mathrm{N}\right)$, total organic carbon, biological oxygen demand (BOD), chemical oxygen demand (COD), total coliform, alkalinity, orthophosphate phosphorus $\left(\mathrm{PO}_{4}{ }^{3-}-\mathrm{P}\right)$, total phosphorus and chlorophyll-a. The monitoring was conducted to see how the water quality changed along the stream in response to various anthropogenic activities. Besides, a paired t-test was utilized to determine the concentration differences at stations above and below the single most important point source of pollutants (Eskişehir city). Moreover, a regression model was used to establish relations between water quality parameters and flow and to estimate nonpoint source loadings.

Keywords: Water quality, stream monitoring, nonpoint sources, point sources, linear regression, Eskisehir, Porsuk Stream, chloride, total phosphorus.

\section{Introduction}

Increasing water demand is a growing issue especially in countries with high population. In tandem, water pollution has become a serious problem due to anthropogenic activities such as urban, industrial, agricultural applications, and also natural processes like erosion (An et al., 2014; J. Vieira et al., 2012a, 2012b). As they are easily accessible, surface waters have potential risks of being polluted and also, they are intentionally used for disposal of wastes (Rashid and Romshoo, 2013).
The determination of water quality is extremely important nowadays to preserve natural ecosystem functions of water bodies and a good quality water is necessary for public health, drinking purposes and irrigation.

Water temperature affects biological and chemical processes and so directly influences concentrations of water quality constituents. Dissolved oxygen determines the degree of water pollution, also concentration of organic matter. If the dissolved oxygen level is under $3 \mathrm{mg} / \mathrm{L}$, it means poor water quality (Turkish Water Pollution Control Regulation). $\mathrm{pH}$ is an indicator for monitoring quality of water, plant formation increases the $\mathrm{pH}$ and affects the reactions (Rodrigues et al., 2011). Sediment is an important cause of pollution which decreases water quality. Suspended particles increase turbidity and affect aquatic plant growth. They also carry with heavy metals to the water sources. Moreover, pathogens can enter surface waters from many sources especially waste water treatment plants, domestic effluents and municipal discharge.

Nutrient loading (especially nitrogen and phosphorus) into water sources is one of the main causes of pollution which results in eutrophication (Kilonzo et al., 2014). It is related with industrial and agricultural activities such as mining, combustion, wastewater treatment, fertilizers (Wu et al., 2012).

The primary aim of this study is to assess the water quality of the Porsuk Stream and to determine the influence of discharges from the city of Eskişehir to the Porsuk Stream. 21 water quality parameters were measured which are water temperature (T), $\mathrm{pH}$, dissolved oxygen (DO), electrical conductivity (EC), salinity, turbidity, chloride, suspended solids, dissolved solids, organic nitrogen (Org$\mathrm{N})$, ammonium nitrogen $\left(\mathrm{NH}_{3}-\mathrm{N}\right)$, nitrite nitrogen $\left(\mathrm{NO}_{2}-\mathrm{N}\right)$, nitrate nitrogen $\left(\mathrm{NO}_{3}-\mathrm{N}\right)$, total organic carbon, biological oxygen demand (BOD), chemical oxygen demand (COD), total coliform, alkalinity, orthophosphate phosphorus $\left(\mathrm{PO}_{4}{ }^{3-}-\mathrm{P}\right)$, total phosphorus and chlorophyl-a. The increase in water pollution is traced along the stream from the Porsuk Reservoir to the confluence with the Sakarya River. 
Moreover, a regression-based technique is applied to separate point source loads from total loads carried by the stream and thus to estimate diffuse loads.

\section{Materials and methods}

\subsection{Study area}

The Porsuk Stream arises from the Murat Mountain, has a length of $460 \mathrm{~km}$ and the drainage area is $11325 \mathrm{~km}^{2}$. The stream has great importance as a domestic water resource for Eskişehir and Kütahya. Its water are also used for irrigation purposes and withdrawn for industrial and mining use (Albek, 2003). A variety of domestic and industrial wastewaters have been discharged without any treatment for years to the stream.

In addition to various activities like agriculture, mining, livestock; industrial associations from the city of Eskişehir and Kütahya apply environmental pressures to the watershed intensively. Therefore the Porsuk Stream is exposed to heavy pollution and this also affects the users negatively.

The study area selected in this work is the stream course after the Porsuk Reservoir (Figure 1). the length of the stream is $460 \mathrm{~km}$ from the reservoir to its mouth and the watershed area is $11325 \mathrm{~km}^{2}$.

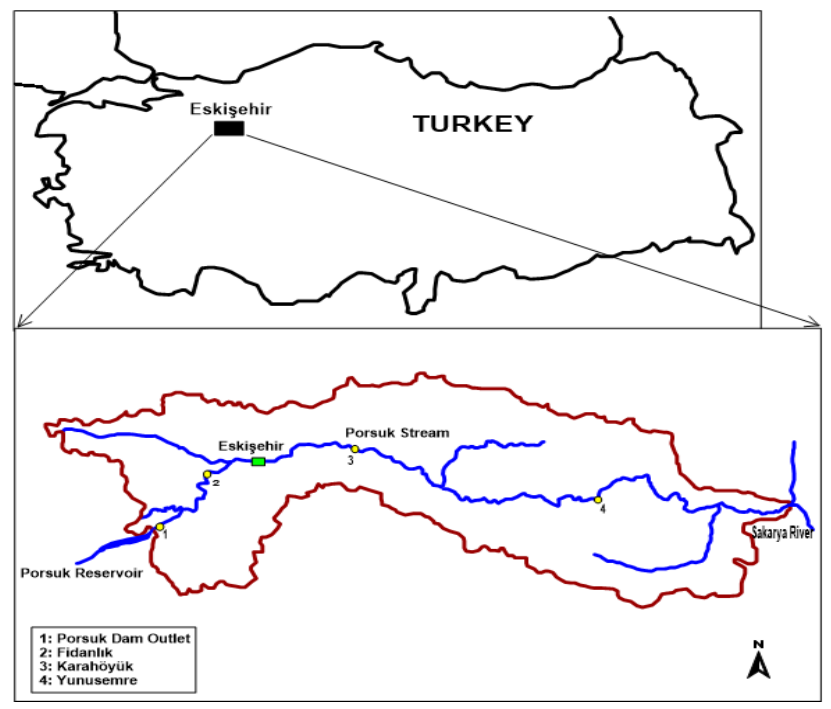

Figure 1. The study area and sampling stations

In the study area, the summers are hot and dry, while winters are cold and rainy in the March, April, November, December, typical of a continental climate. Eskişehir's average annual temperature is $10.6^{\circ} \mathrm{C}$, and average total rainfall is $347 \mathrm{~mm}$ as observed between the years of 1975-2009 (Turkish State Meteorological Service).

\subsection{Sampling}

Water samples were collected at four stations on the Porsuk Stream (Figure 1). The first station is situated at the outlet of the Porsuk Dam and is chosen to represent the stream input into the watershed and as a boundary condition. The second station is located just before the stream enters the city of Eskişehir. The third station is after Eskişehir, in the Karahöyük Village. These two stations, one before and one after the city, are chosen to determine how domestic and industrial wastewaters and storm water affect the water quality of the stream. The last station is at the Yunusemre Village which is located before the Porsuk Stream flows into the Sakarya River.

The water samples were collected at monthly intervals from 2008 to 2010. $\mathrm{pH}$, dissolved oxygen, conductivity, salinity, total dissolved solids measurements were performed in situ with Hach portable "SENSION 156", with potable WTW turbidity meter, Turbidity analyses were carried out. In addition, at each station, flow and stream crossection measurements were done with SONTEK RiverSurvoyer M9 Acoustic Doppler equipment.

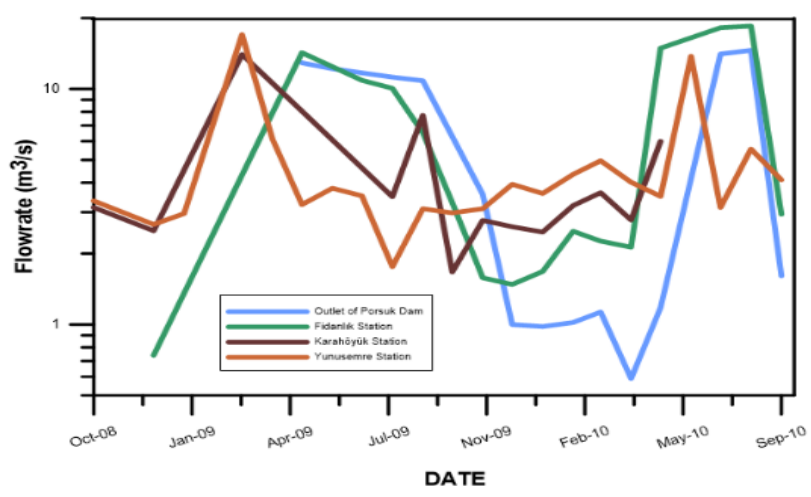

Figure 2. Flowrate at sampling stations

The flowrates at the 4 respective stations are presented in Figure 2. the monitoring period extends from October 2008 to September 2010, thus spanning two complete water years.

\subsection{Laboratory analysis}

Ruttner water sampling equipment was used for taking water samples from different sections of the stream and composite samples were formed. Some part of the samples were placed to the plastic bottles and the others were kept in acid solutions and brought to the laboratory with ice moulds so laboratory analyses were carried out.

The laboratory analysis for nitrogen, phosphorus and COD were performed by the methods adopted by USEPA. Hach DR2400 spectrophotometer was used for analysing water samples. Other analyses were done according to the Standard Methods for the Examination of Water and Wastewater (APHA) (Table 1).

\section{Results}

\subsection{Monitoring results}

The monitoring results are displayed as box and whisker plots throughout the figures. This type of display allows the utilization of all data in a compact manner, showing the central location (median) and spread (IQR, interquartile range) of the data. Inclusion of all stations in 
the same figure shows how the water quality changes along the stream.

Figure 3 shows the total alkalinity and $\mathrm{pH}$ at the four stations. The stream is slightly on the alkaline side. The observation before Eskişehir (Station 1 and 2, Outlet of Prosuk Dam and Fidanlık) and after Eskişehir (Station 3 and 4, Karahöyük and Yunusemre) show marked differences. A t-test for means before and after Eskişehir (Table 2) confirms this. The result is a consequence of different pollution types and levels. Before Eskişehir, the stream is burdened primarily by equalized pollutant loads from the Porsuk Dam and afterwards by point and diffuse loads from various activities.

Table 1. Analysis that made in the laboratory

\begin{tabular}{|c|c|}
\hline Analysis & Explanation \\
\hline Coliform & $\begin{array}{l}\text { Endo NKS-Membrane filtration process is used at first but, } 3 \text {. And } 4 \text {. Stations had too much } \\
\text { colony because heavy polluted, then Colilert-18 process, which is more sensitive, was used. }\end{array}$ \\
\hline Nitrogen species & $\begin{array}{l}\text { DR2400 water analyse spectrophotometer was used to measure nitrogen ammonium with } \\
\text { Nessler process, nitrite nitrogen and nitrate nitrogen both lower and higher concentrations } \\
\text { were determined. (For nitrate-N; cadmium reduction method was used. For Nitrite-N; } \\
\text { diazotization method was used. For Ammonium-Nitrogen; Nessler Method was used. For total } \\
\qquad \mathrm{N} \text {; per sulphate digestion method was used.) }\end{array}$ \\
\hline Phosphorus types & $\begin{array}{c}\text { DR2400 water analyse spectrophotometer was used to measure orthophosphate and total } \\
\text { phosphorus. (For total phosphorus with per sulphate digestion method was used. For } \\
\text { orthophosphate ascorbic acid method was used.) }\end{array}$ \\
\hline Suspended solids and dissolved solids & $\begin{array}{l}\text { Gravimetric analyse processes were used. Water samples were filtered through membrane } \\
\text { filter ( } 0.45 \mu \mathrm{m} \text { pore size) and Sartorious filtration apparatus was used. (According to Standard } \\
\text { method } 2540 \text { D was used.) }\end{array}$ \\
\hline Chlorophyl-a & According to Standard Methods $(10200 \mathrm{H})$ it analysed with spectrophotometer. \\
\hline Chloride & Standard volumetric method was used. (8113 mercury thiocyanate method was used.) \\
\hline Alkalinity & Standard volumetric method was used. \\
\hline Sulfate & DR2400 water analyse spectrophotometer was used. (8051 SulfaVer4 method was used.) \\
\hline Chemical oxygen demand & $\begin{array}{l}\text { DR2400 water analyse spectrophotometer was used for determining chemical oxygen } \\
\text { demand (Method 8000). }\end{array}$ \\
\hline Biological oxygen demand & Standard volumetric method was used. \\
\hline Total organic carbon & $\begin{array}{c}\text { According to Standard Method } 3510 \text { B, Shimadzu VCPH-5000 model Total Organic Carbon } \\
\text { analyser was used. }\end{array}$ \\
\hline
\end{tabular}

Water temperature changes in accordance with the air temperature (Anyanwu et al., 2013) As seen in Figure 4, temperature values range from $0-25^{\circ} \mathrm{C}$ according to seasons. The lower medians and IQR in the first 2 Station point to the equalizing effect of the Porsuk Dam. The temperatures in the second part of the stream (after Eskişehir) are higher as the effects of the low reservoir release temperatures are diminishing. The dissolved oxygen levels (Figure 4) show a reverse picture compared to temperature but the decrease in the dissolved oxygen levels stems from the high organic pollution loads after Eskişehir due to mostly domestic and industrial wastewaters.

Dissolved solids in streams emanate as a result of mineral weathering. They are also present in wastewater. The main sources of suspended solids include runoff, storm water, landfills, construction and transportation activities, inadequate treatment plants, heavy precipitation, erosion and agriculture (Al-Badaii et al., 2013; Horowitz, 2009). Moreover, high turbidity indicates that water contains suspended particles such as silt, plankton, clay, organic matter and other organisms so there is a relationship between suspended solid concentration and turbidity
(Al-Badaii et al., 2013). After the city of Eskişehir, both Eskişehir's impact to the stream and irrigation water from agriculture increase solids and high concentrations are observed, but after 2010, as a consequence of the opening of the wastewater Eskişehir new treatment plant, the average suspended solid concentration decreased (Albek et al., 2011).

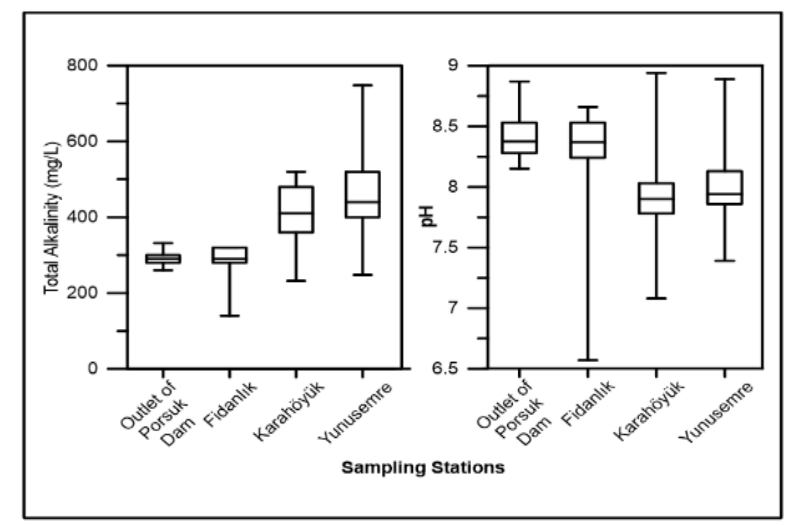

Figure 3. Total alkalinity (left) and pH (right side) values at the sampling stations 


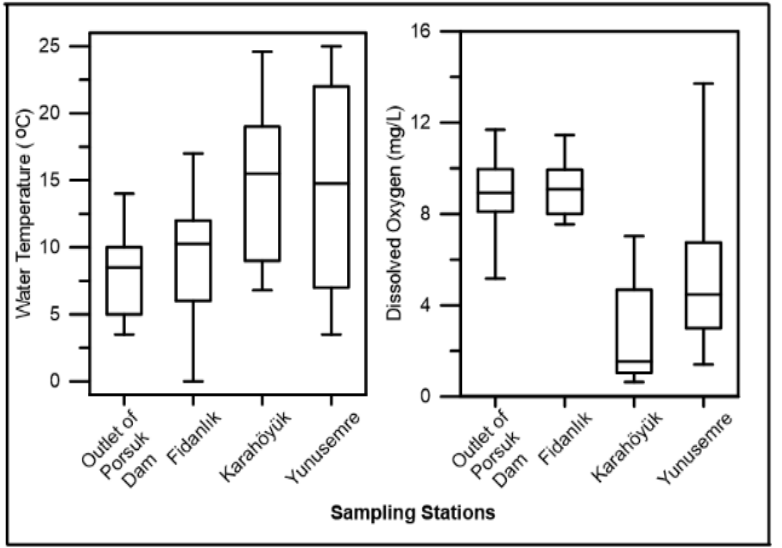

Figure 4. Water temperature and dissolved oxygen concentration at the sampling stations

Chloride is present in surface waters and is essential for biological functions (Elphick et al., 2011). The main source of chloride is road salts which are used on roads and parking lots in winter (Trowbridge et al., 2010). As with dissolved and suspended solids, chlorides also show increases in the second part of the stream (Figure 5).

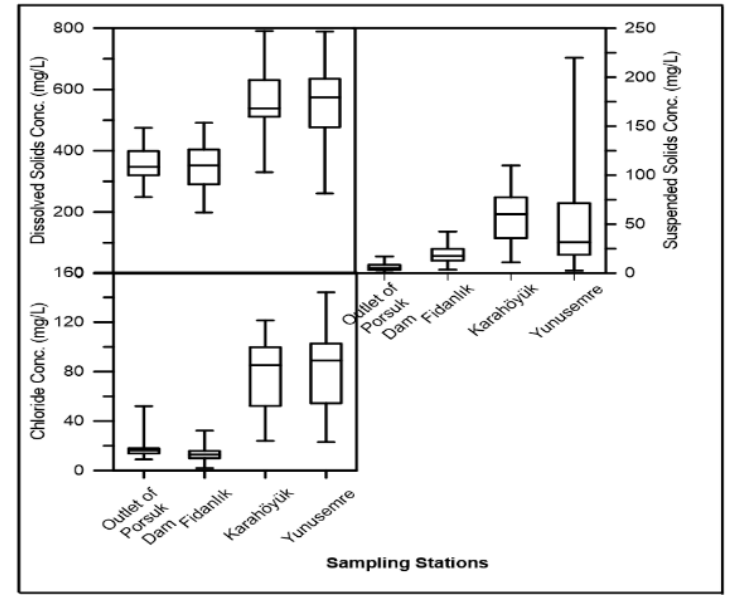

Figure 5. Dissolved, suspended solids and chloride concentration at the sampling stations

Nitrogen comes from agricultural areas using fertilizers, acid water, industrial waste are the main source of nonpoint pollution and can cause eutrophication of surface waters (Cabezas et al., 2013; He et al., 2011; Hutchins, 2012; Zheng et al., 2004). Nitrogen exists in waters in several forms; nitrate, nitrite, ammonium and organic nitrogen. Nitrate, nitrite, ammonia and organic nitrogen levels of surface waters are the main indicators of water quality. Nitrite and nitrate is formed biodegradation of ammonia and other nitrogenous organic matter (Connolly and Paull, 2001).

Ammonia nitrogen mean concentration at the first station is decreasing at the second station. At the third and fourth stations the average concentration value is increasing. It was determined that the ammonia nitrogen coming from Porsuk Dam was reduced with aeration until second station. On the other hand, at other stations (after Eskişehir) agricultural fertilizer and bacterial decomposition rises the concentration of nitrogen (Albek et al., 2011). Nitrite concentrations are at very low levels at each stations between 0.02- $0.1 \mathrm{mg} / \mathrm{L}$. Organic nitrogen average concentration at 1., 2. and 4. Stations are nearly same values, otherwise at 3 . Station the concentration is maximum $(5.6 \mathrm{mg} / \mathrm{L})$. Nitrate nitrogen concentrations are very low levels.

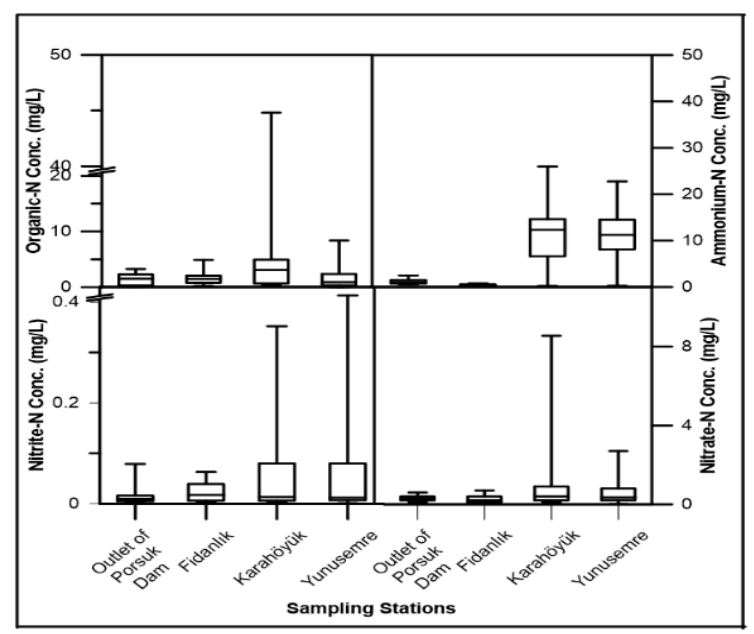

Figure 6. Organic- $\mathrm{N}$, ammonium- $\mathrm{N}$, nitrate- $\mathrm{N}$ and nitrite- $\mathrm{N}$ concentrations at the sampling stations

Phosphorus, one of the most important nutrients of primary concern that causes eutrophication and water pollution like nitrogen, which is also found in urban storm water runoff has been measured as one of the water quality parameters. Most of the soluble phosphorus in storm water and wastewater is generally present in the orthophosphate form. Orthophosphate reaches streams from different sources. Being the bioavailable form for algae, orthophosphate is very important for natural waters (Komlos and Traver, 2012). Also, phosphorus is a plant nutrient and an important ingredient in fertilizers. As rain washes off fertilized soils, some of the phosphorus is carried into streams. Most of the phosphorus not taken up by growing plants is bound to soil particles and carried into streams with soil erosion. Also, it is indicated that phosphorus and suspended solids are highly correlated in agricultural watersheds (Wall et al., 1996). Other sources of phosphorus are detergents, biogenic materials, animal wastes, natural P-containing soils, human and animal excrements, food-processing wastes, atmospheric deposition and runoff from urban areas (Berretta and Sansalone, 2011; Coulter et al., 2004). Urban watersheds typically carry 5 to 20 times as much phosphorus per unit area per year, as compared to undeveloped watersheds in a given region (Walker, 1987).

As expected, the influence of Eskişehir is clearly seen in Figure 7 as elevated concentrations in the latter station. 
Chrophly_a also shows elevated concentration at the stations after Eskişehir due to increased levels of phosphorus and nitrogen. Microorganisms are point and non-point source pollutants in surface waters which can not be controlled easily (Cheng et al., 2013). Moreover microbiological pollution of surface waters are originated from waste water discharges $21 * 10^{5} \mathrm{MPN} / 100 \mathrm{~mL}$ at third station (because of fresh wastewater discharge from the plant) and at fourth station it decreases $4.2 * 10^{5} \mathrm{MPN} / 100 \mathrm{~mL}$ with dilution.

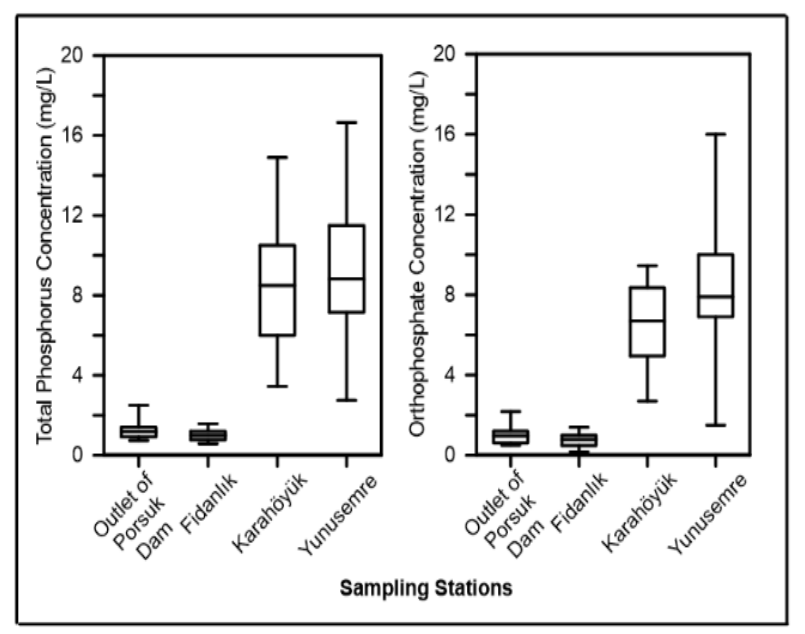

Figure 7. Total phosphorus and orthophosphate concentration at the sampling stations

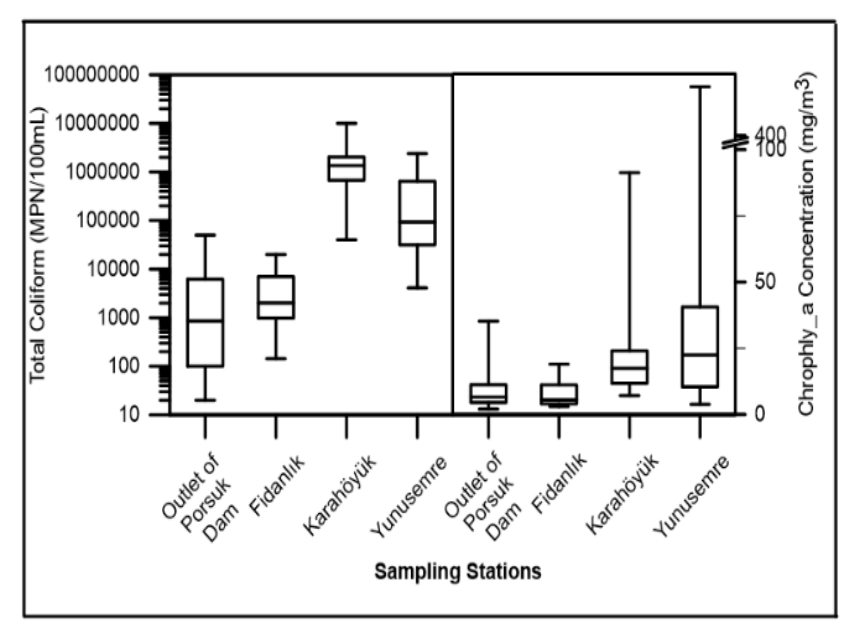

Figure 8. Total coliform and chrophly-a concentration at the sampling stations

Generally, organic pollution is determined by biochemical oxygen demand (BOD). BOD is an indicator of biological activity and gives proof about organic waste and it also relates with dissolved oxygen (Basant et al., 2010; Guwy et al., 1999). The BOD of water sources is a needed parameter for assessment of water quality and to develop management strategies (Basant et al., 2010). Since BOD takes at least 5 days, different analysis such as COD or TOC are used for monitoring and modelling (Dubber and Gray, 2010). In this study BOD, COD and TOC were measured at each station. As seen in Figure 9, the stations after Eskişehir have higher concentrations of the organic pollution parameters and temporal peaks are also encountered.

Table 2. Parameters percentage differences of averages

\begin{tabular}{|c|c|c|}
\hline Parameters & $\begin{array}{l}\text { Percentage Difference } \\
\text { of Averages (\%) }\end{array}$ & $p$-value \\
\hline $\mathrm{pH}$ & 5 & $<0.05$ \\
\hline Total Alkalinity & 38 & $<0.05$ \\
\hline Water Temperature & 51 & $<0.05$ \\
\hline Dissolved oxygen & 80 & $<0.05$ \\
\hline Dissolved Solids & 28 & $<0.05$ \\
\hline Suspended Solids & 124 & $<0.05$ \\
\hline Chloride & 136 & $<0.05$ \\
\hline Nitrate-N & 72 & $<0.05$ \\
\hline Nitrite-N & 122 & $<0.05$ \\
\hline Ammonium-N & 175 & $<0.05$ \\
\hline Organic N & 66 & $<0.05$ \\
\hline Total Phosphorus & 155 & $<0.05$ \\
\hline Orthophosphate & 157 & $<0.05$ \\
\hline Total Coliform & 198 & $<0.05$ \\
\hline Chrophly-a & 132 & $<0.05$ \\
\hline$*=\frac{\frac{\text { Mean }_{1}-\text { Mean }_{2}}{\frac{\text { Mean }_{1}+\text { Mean }_{2}}{2}}}{2}$ & $* 100$ & \\
\hline
\end{tabular}

A paired t-test was performed between the average concentrations of the first and second stations and the average concentrations of the third and fourth stations to statistically determine the effect of increasing constituent concentrations and other water quality parameters $(\mathrm{pH}$, temperature). Table 2 presents the results. The $p$-values below 0.05 confirm that the differences between the $1^{\text {st }}+2^{\text {nd }}$ and $3^{\text {rd }}+4^{\text {th }}$ stations are statistically significant. The percentage difference of averages is a measure of how much the difference amounts.

\subsection{Determination of nonpoint source loads}

Nonpoint source loads entering a stream are very difficult, even impossible in cases, to measure. The reason is that nonpoint sources emanating from a watershed enter a stream at many and mostly unrecognizable points and intermittently, generally after precipitation events. Therefore, nonpoint or diffuse source loads to a stream are most of the time only estimated. One technique to estimate such source loads is given in Albek (2003). 


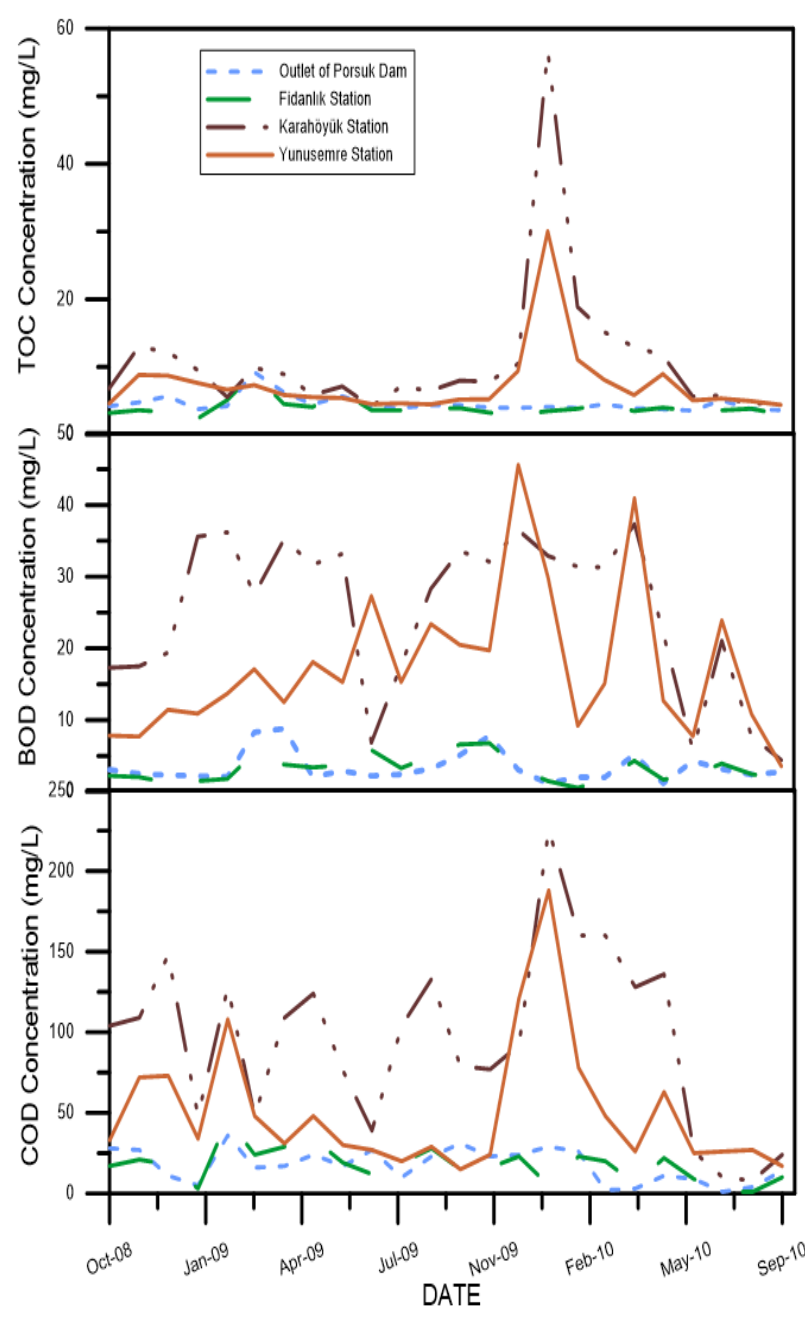

Figure 9. TOC, BOD, COD concentrations at the sampling stations

If streamflow and water quality constituent concentration measurements are available at two adjacent monitoring stations, an average load can be obtained for the water quality constituent by a suitable technique, multiplying the flow with concentration being the simplest one. If there are point and nonpoint sources between the stations, the load in the downstream station will be larger than the load at the first station by the amount contributed from the sources. The situation is schematized in Figure 10 as:

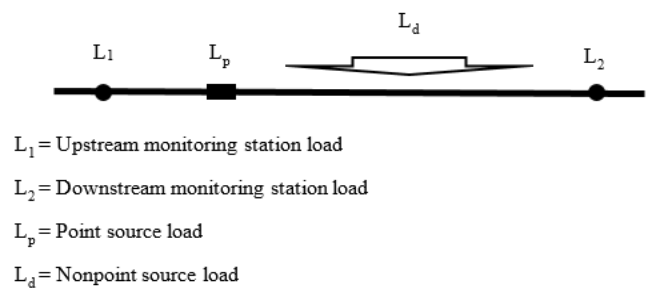

Figure 10. Point and nonpoint source loads to a stream between two monitoring stations
If the stations are not widely-spaced and the water quality constituent can be regarded as conservative, the following relationship will hold:

$$
L_{2}=L_{1}+L_{p}+L_{d}
$$

The point source loads can be estimated from a regression model as given below:

$$
C=\frac{a}{Q}+b
$$

In this equation $a$ is the point source load, $b$ is the background concentration and $C$ and $Q$ are water quality concentration a streamflow, respectively. The expression is obtained from a mass balance around a point source to a stream as follows:

$$
C Q=a+b Q
$$

where $C Q$ is the load after the point source and it is composed of the point source load (a) and the background load (bQ) brought by the stream. The equation (2) holds if the point source adds a negligible flow to the stream compared to the streamflow (Albek, 1999).

Streamflow and constituent concentration relationships for the Fidanlık and Karahöyük stations are displayed for chloride, dissolved solids, BOD, total phosphorus and nitrate in Figures 11 and 12. In the Fidanlık station, the equalizing effects of the Porsuk Reservoir are still felt and as there are no appreciable point sources upstream, an inverse relationship as would be predicted by Eq. 2 is not detectable. However, in the Karahöyük station after the city of Eskişehir, the inverse relationship is readily seen, except for BOD which is not a conservative constituent and nitrate. The strength of the relationships are given with the coefficient of determination $\left(r^{2}\right)$ values as; for chloride 0.82; total phosphorus 0.53; dissolved solids 0.37; nitrate 0.04 and BOD 0.02. Thus, nitrate and BOD were left out of the analysis as their point source loads cannot be determined from the inverse relationship above.

Based on water quality data collected between 20082010, the loads at the Fidanlık $\left(L_{1}\right)$ and Karahöyük $\left(L_{2}\right)$ stations have been calculated from the observations by multiplying flowrates with the corresponding concentrations. Thus simple estimates of loads were obtained as displayed in Table 3. Point source loads $\left(L_{p}\right)$ are found by regression analysis after Eq. 2 was linearized as follows:

$$
C=a Q^{\prime}+b
$$

where $Q^{\prime}$ is the reciprocal of $Q$. Performing a linear regression analysis, gives the coefficients $a$ and $b$. $a$ is equal to the point source load $L_{p}$.

The diffuse loads $\left(L_{d}\right)$ were calculated from Eq. 1 and are given in Table 3. 


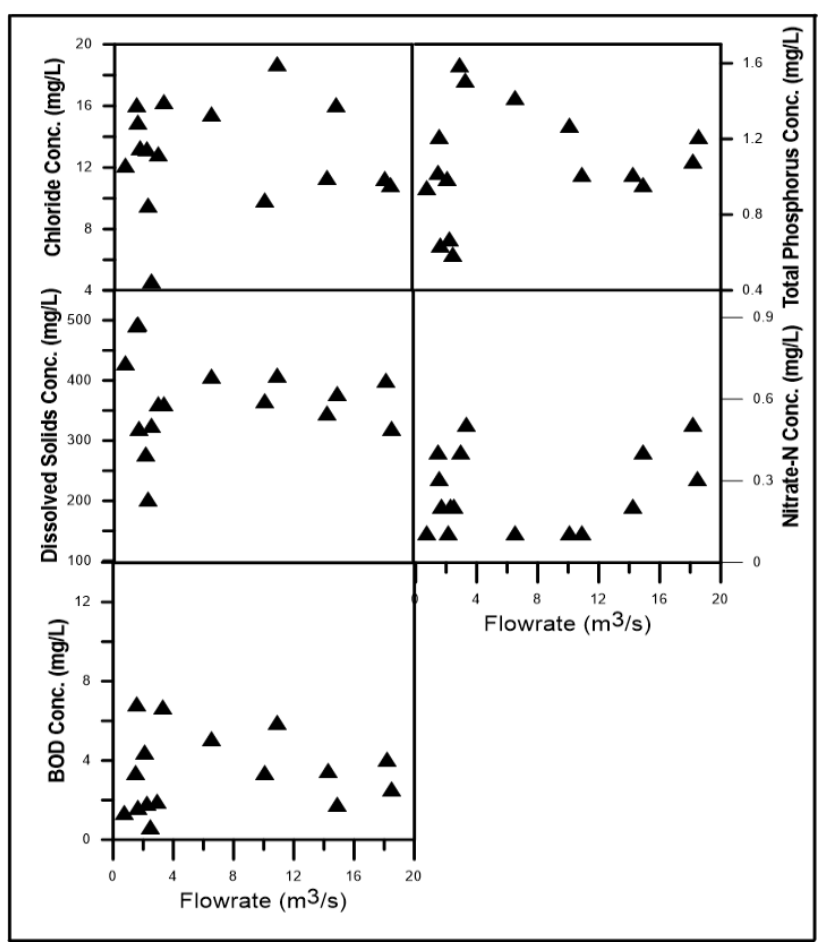

Figure 11. The concentration and flow relationships at Fidanlık Station

As it is seen in Table 3, the load distribution among constituents differ. For total phosphorus, point and diffuse loads are nearly equal. For chloride the point load is around 2.7 times larger than the diffuse load. Considering $6 \mathrm{~g} /$ capita.day as the amount of chloride a person is likely to contribute to the sewer system (Sawyer and McCarthy, 1978), the point load contribution corresponds to 2500000 people. This is around 4 times the population which lives in the region from where the point loads originate (Eskişehir). The rest must then come from industrial sources.

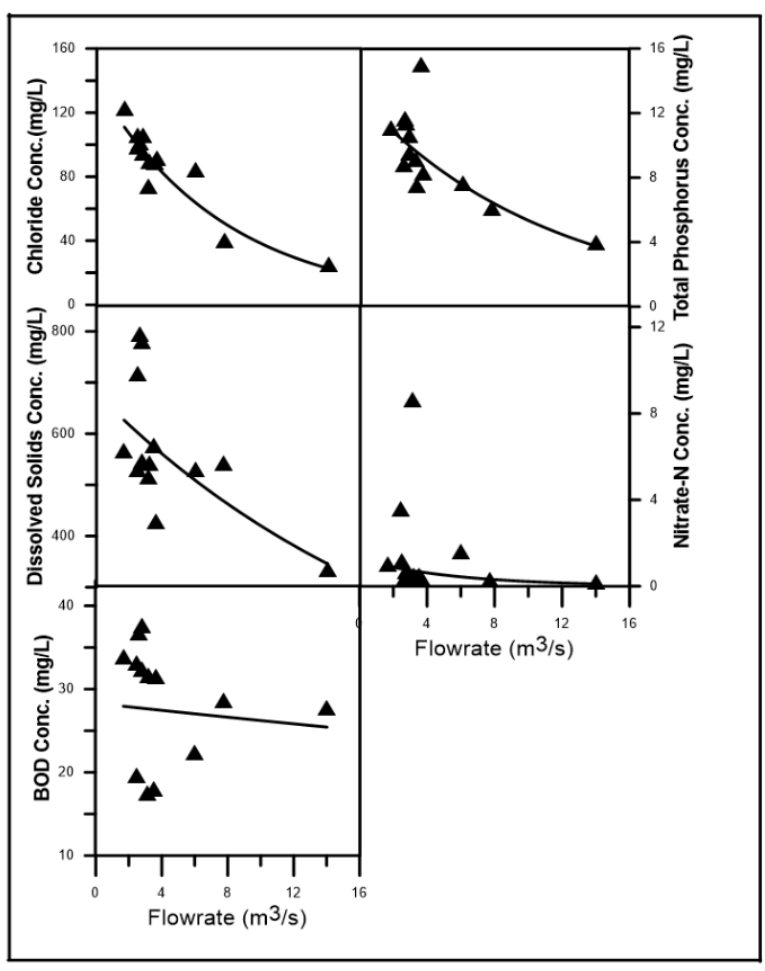

Figure 12. The concentration and flow relationships at Karahöyük Station

Table 3. Load estimates based on regression coefficients

\begin{tabular}{ccccc}
\hline \multirow{2}{*}{ Parameter } & Fidanlık load, $\mathbf{L}_{\mathbf{1}}$ & Point load, $\mathrm{L}_{\boldsymbol{p}}$, $\mathbf{a}$ Diffuse load, $\mathrm{L}_{\boldsymbol{d}}$ & Karahöyük load, $\mathbf{L}_{\mathbf{2}}$ \\
\cline { 2 - 5 } & \multicolumn{5}{c}{ (tons/year) } \\
\hline Chloride & 1947 & 5479 & 1976 & 9401 \\
\hline Dissolved solids & 53230 & 480 & 12460 & 66170 \\
\hline Total phosphorus & 159 & 410 & 442 & 1010 \\
\hline
\end{tabular}

For dissolved solids, the diffuse loads greatly (by a factor of 25) dominate over the point loads. But here it must be pointed out that the relationship between dissolved solids and streamflow is a rather weak one as seen in Figure 11 and quantified in the coefficient of determination value of 0.37 . It can be argued that the analysis above greatly underestimated the dissolved solids point loads.

\subsection{Classification of Porsuk Stream}

In Turkey, the legal regulations related with water pollution parameters and control are published as "Turkish Water Pollution Control Regulation" (TWPCR) at the official gazette. The aims of this regulations are to protect water sources from pollution and to improve water quality of water. According to this regulation, Table 4 gives the Porsuk River classified as polluted water due to the presence of Class IV parameters (Turkey, 30 November 2012).
The regulations categorize the pollution classes as follows;

I. High-quality water (Class 1; surface waters with a high potential for drinking water, available water for recreational purposes, trout, animal production, and farm needs.)

II. Slightly polluted water (Class 2; surface waters with a potential for drinking water, available water for fish production other than trout and irrigation.)

III. Polluted water (Class 3; except for facilities requiring qualified water, such as food and textile, it can be used for aquaculture after proper treatment.)

IV. Highly polluted water (Class 4; it has a lower quality than the quality parameters given for Class III and that can be only be achieved by improving the top quality class.) 
Table 4. Quality class of Porsuk Stream

\begin{tabular}{|c|c|c|c|c|c|c|c|}
\hline \multirow{2}{*}{ Stations } & \multicolumn{7}{|c|}{ The studied water-quality variables } \\
\hline & $p H$ & Temperature & Dissolved Oxygen & $\mathrm{NH}_{4}^{+-} \mathrm{N}$ & $\mathrm{NO}_{2}-\mathrm{N}$ & $\mathrm{NO}_{3}-\mathrm{N}$ & Total $\mathrm{PO}_{4}^{-3}$ \\
\hline Outlet of Porsuk Dam & 1 & 1 & 1 & II & II & 1 & III \\
\hline Fidanlık & 1 & 1 & 1 & 1 & II & 1 & III \\
\hline Karahöyük & 1 & 1 & IV & IV & III & 1 & IV \\
\hline \multirow[t]{2}{*}{ Yunusemre } & I & 1 & III & IV & IV & 1 & IV \\
\hline & Dissolved Solids & Chloride & Total Coliform & $B O D$ & $C O D$ & TOC & \\
\hline Outlet of Porsuk Dam & 1 & 1 & II & II & II & II & \\
\hline Fidanlık & 1 & 1 & II & II & II & II & \\
\hline Karahöyük & II & II & IV & IV & IV & IV & \\
\hline Yunusemre & II & II & IV & IV & IV & IV & \\
\hline
\end{tabular}

\section{Discussion and conclusion}

In this study, the state of pollution of the Porsuk Stream and the impacts of urban contributions on water quality were determined. The natural sources especially agricultural applications are found to be the main water pollution sources. As a result of point and nonpoint sources discharges, after Eskişehir (Karahöyük and Yunusemre Stations) the water quality concentrations increase and the class of Porsuk Stream is changing from polluted or highly polluted water. Especially, nitrogen and phosphorus compounds are increasing.

The analysis in 3.2 enables, albeit for a small number of conservative substances, the estimation of nonpoint source contributions which are otherwise very difficult to determine. Thus, it is a technique which can be applied to fill in gaps in observational data in efforts to determine the status of a stream and to estimate loads which aid to develop abatement strategies to reduce pollution and its effects.

\section{Acknowledgements}

The authors are indebted to the research fund of the Scientific and Technological Research Council of Turkey for supporting this study under a project entitled "Investigation of the Effects of Climate Change on the Hydrology and Water Quality of the Lower Porsuk Stream Watershed Using HSPF and Determination of Best Water Management Strategies" under project number 108 Y091.

\section{References}

Al-Badaii F., Shuhaimi-Othman M. and Gasim M.B. (2013). Water Quality Assessment of the Semenyih River, Selangor, Malaysia. Journal of Chemistry.

Albek E. (1999). Identification of the different sources of chlorides in streams by regression analysis using chloridedischarge relationships. Water Environment Research, 71(7), 1310-1319.

Albek E. (2003). Estimation of point and diffuse contaminant loads to streams by non-parametric regression analysis of monitoring data. Water Air and Soil Pollution, 147(1-4), 229243.

Albek E., Albek M. and Goncu S. (2011). Investigation of The Effects of Climate Change On The Hydrology and Water Quality of The Lower Porsuk Stream Watershed Using HSPF and Determination of Best Water Management Strategies. The Scientific and Technological Research Council of Turkey, Scientific and Technological Research Project:

An Y., Zou Z.H. and Li R.R. (2014). Water Quality Assessment in the Harbin Reach of the Songhuajiang River (China) Based on a Fuzzy Rough Set and an Attribute Recognition Theoretical Model. International Journal of Environmental Research and Public Health, 11(4), 3507-3520.

Anyanwu E.D., Ikomi R.B. and Arimoro F.O. (2013). Water quality and zooplankton of the Ogba River, Benin City, Nigeria. African Journal of Aquatic Science, 38(2), 193-199.

Basant N., Gupta S., Malik A. and Singh K.P. (2010). Linear and nonlinear modeling for simultaneous prediction of dissolved oxygen and biochemical oxygen demand of the surface water - A case study. Chemometrics and Intelligent Laboratory Systems, 104(2), 172-180.

Berretta C. and Sansalone J. (2011). Speciation and Transport of Phosphorus in Source Area Rainfall-Runoff. Water Air and Soil Pollution, 222(1-4), 351-365.

Cabezas A., Gelbrecht J. and Zak D. (2013). The effect of rewetting drained fens with nitrate-polluted water on dissolved organic carbon and phosphorus release. Ecological Engineering, 53, 79-88.

Cheng J., Niu S. and Kim Y. (2013). Relationship between water quality parameters and the survival of indicator microorganisms - Escherichia coli - in a stormwater wetland. Water Science and Technology, 68(7), 1650-1656.

Connolly D. and Paull B. (2001). Rapid determination of nitrate and nitrite in drinking water samples using ion-interaction liquid chromatography. Analytica Chimica Acta, 441(1), 5362.

Coulter C.B., Kolka R.K. and Thompson J.A. (2004). Water quality in agricultural, urban, and mixed land use watersheds. Journal of the American Water Resources Association, 40(6), 1593-1601.

Dubber D. and Gray N.F. (2010). Replacement of chemical oxygen demand (COD) with total organic carbon (TOC) for monitoring wastewater treatment performance to minimize disposal of toxic analytical waste. Journal of Environmental Science and Health Part a-Toxic/Hazardous Substances \& Environmental Engineering, 45(12), 1595-1600.

Elphick J.R.F., Bergh K.D. and Bailey H.C. (2011). Chronic Toxicity of Chloride to Freshwater Species Effects of Hardness and Implications for Water Quality Guidelines. Environmental Toxicology and Chemistry, 30(1), 239-246. 
Guwy A.J., Farley L.A., Cunnah P., Hawkes F.R., Hawkes D.L., Chase M. and Buckland H. (1999). An automated instrument for monitoring oxygen demand in polluted waters. Water Research, 33(14), 3142-3148.

He L.J., Zhang K.G., Wang C.J., Luo X.L. and Zhang S.S. (2011). Effective indirect enrichment and determination of nitrite ion in water and biological samples using ionic liquiddispersive liquid-liquid microextraction combined with highperformance liquid chromatography. Journal of Chromatography A, 1218(23), 3595-3600.

Horowitz A.J. (2009). Monitoring suspended sediments and associated chemical constituents in urban environments: lessons from the city of Atlanta, Georgia, USA Water Quality Monitoring Program. Journal of Soils and Sediments, 9(4), 342-363.

Hutchins M.G. (2012). What impact might mitigation of diffuse nitrate pollution have on river water quality in a rural catchment? Journal of Environmental Management, 109, 1926.

Kilonzo F., Masese F.O., Van Griensven A., Bauwens W., Obando J. and Lens P.N.L. (2014). Spatial-temporal variability in water quality and macro-invertebrate assemblages in the Upper Mara River basin, Kenya. Physics and Chemistry of the Earth, 67-69, 93-104.

Komlos J. and Traver R.G. (2012). Long-Term Orthophosphate Removal in a Field-Scale Storm-Water Bioinfiltration Rain Garden. Journal of Environmental Engineering-Asce, 138(10), 991-998.

Rashid I. and Romshoo S.A. (2013). Impact of anthropogenic activities on water quality of Lidder River in Kashmir Himalayas. Environmental Monitoring and Assessment, 185(6), 4705-4719.

Rodrigues B.D., De Sagazan O., Crand S., Mohammed-Brahim T. and Morimoto N.I. (2011). pH meter based in Suspended Gate Field Effect Transistors to application in monitoring of water quality. Microelectronics Technology and Devices Sbmicro 2011, 39(1), 291-298.

Trowbridge, P.R., Kahl J.S., Sassan D.A., Heath D.L. and Walsh E.M. (2010). Relating Road Salt to Exceedances of the Water Quality Standard for Chloride in New Hampshire Streams. Environmental Science \& Technology, 44(13), 4903-4909.

Turkey O.G.o.t.R.o. (30 November 2012). Surface Water Quality Management Law. Official Gazette of the Republic of Turkey(28483).

Vieira J., Fonseca A., Vilar V.J.P., Boaventura R.A.R. and Botelho C.M.S. (2012a). Water quality in Lis river, Portugal. Environmental Monitoring and Assessment, 184(12), 71257140.

Vieira J.S., Pires J.C.M., Martins F.G., Vilar V.J.P., Boaventura R.A.R. and Botelho C.M.S. (2012b). Surface Water Quality Assessment of Lis River Using Multivariate Statistical Methods. Water Air and Soil Pollution, 223(9), 5549-5561.

Walker J. (1987). Reflections from a Water-Surface Display Some Curious Properties. Scientific American, 256(1), 120-124.

Wall, G.J., Bos A.W. and Marshall A.H. (1996). The relationship between phosphorus and suspended sediment loads in Ontario watersheds. Journal of Soil and Water Conservation, 51(6), 504-507.

Wu J.L., Zeng H.A., Yu H., Ma L., Xu L.S. and Qin B.Q. (2012). Water and Sediment Quality in Lakes along the Middle and
Lower Reaches of the Yangtze River, China. Water Resources Management, 26(12), 3601-3618.

Zheng F.L., Huang C.H. and Norton L.D. (2004). Surface water quality - Effects of near-surface hydraulic gradients on nitrate and phosphorus losses in surface runoff. Journal of Environmental Quality, 33(6), 2174-2182. 